\title{
Risk Factors of Adolescent Aggression
}

\author{
Sandra Sunitha Lobo ${ }^{1 *}$, Dr. S.V. Surya Rekha ${ }^{2}$
}

\section{ABSTRACT}

Adolescence as a transitional stage implies several changes and challenges demanding psychosocial adjustment that could be beyond one's coping for some adolescents who end up developing dysfunctional adaptive behaviour such as aggression. The present study aimed at investigating the risk factors of adolescent aggression. A total of 297 respondents constituted the sample of the study. Among them, 63 (21.21\%) adolescents were male and 234 (78.78\%) were female. A survey design was used. The descriptive statistics used for analysis of demographic variables were frequency and percentage. Chi Square test and Fishers exact test were used to find the risk factors of Aggression. The findings of the present study show a statistical significant association between gender and socio-economic status on adolescent aggression.

Keywords: Adolescent Aggression, Socio-Economic Status, Gender.

There are major developmental changes and challenges associated with the period of adolescence, as youth acquire and consolidate the competencies, attitudes and values necessary to make a successful transition into adulthood. Late adolescence and the period following it, often referred to as emerging adulthood, have been noted as particularly important for setting the stage for continued development through the life span as individuals begin to make choices and engage in a variety of activities that influence rest of their lives.

Bronfenbrenner (2001) in his ecological theory of developmental processes provides a valuable lens for examining developmental changes in adolescent aggression. The family and school environments have regularly been linked to psycho - social and behavioural adjustment problems in the adolescent period. The quality of adolescent - parent, adolescent - peer and adolescent teacher interactions influence and may determine the way adolescents perceive themselves in relation to others, their attitudes and their behaviours. In addition to the family processes, peer contexts in adolescence have implications for adolescent aggression.

\footnotetext{
${ }^{1}$ Research Scholar, Research and Development Centre, Bharathiar University, Coimbatore, India

${ }^{2}$ Professor, Montfort College, Bangalore, India

*Responding Author

(C) 2016 I S Lobo, S Rekha; licensee IJIP. This is an Open Access Research distributed under the terms of the Creative Commons Attribution License (http://creativecommons.org/licenses/by/2.0), which permits unrestricted use, distribution, and reproduction in any Medium, provided the original work is properly cited.
} 


\section{Risk Factors of Adolescent Aggression}

Gender is a factor that plays a role in human aggression. Men are historically believed to be generally more physically aggressive than women (Coie \& Dodge 1997, Maccoby \& Jacklin 1974). This is one of the most robust and reliable behavioural sex differences and has been found across many different age groups and cultures. Rahman and Huq (2005) studied to explore aggression in adolescent boys and girls as related to socio-economic status (SES) and residential background in Bangladesh. They investigated 240 respondents and found that respondents with high SES expressed more aggression than those with middle and low SES. Respondents with middle SES expressed more aggression than the low SES and girls expressed more aggression than boys.

Family is the most important part of a child's environment (Adams, 1966). An individual's experiences in early life at home with his/her family in general and parents in particular are major determinants of a person's adjustment process during adolescence and in later life (Jayanagaraja, 1985). Children of physically punitive parents tend to use similar aggression when relating to others. Their parents often disciplined them by screaming, slapping, and beating - thus modeling aggression as a method of dealing with problems (Patterson, Chamberlain \& Reid, 1982). There exists a relationship between intra familial communication and aggressive behaviours. Van Londen et al (2013), through a cross- sectional study, examined a model in which parenting, child social information processing and self-perception were simultaneously tested as risk factors associated with aggression. Most studies assessing the link between parental discipline and child aggression have focused primarily on discipline as a cause and aggression as an outcome.

Only a paucity of research has examined risk factors for community violence exposure across domains relevant to adolescents. Sharma, Grover and Chaturvedi (2008) conducted a Crosssectional study in South Delhi, India, to assess risk behaviour related to interpersonal violence and its epidemiological correlates among 550 adolescents of various schools and colleges aged 14-19 years. The study identified a significant relationship with age $p=.007)$ and gender $(p \leq$ .001) of the adolescents. The logistic regression analysis of the study showed significant correlation of interpersonal violence with male gender, lower age, and number of close friends, having seen role models who smoke/drink, and reside in resettlement colonies, slums or villages.

Using data from 184 adolescents and their homeroom teacher, analyses with structural equation modelling, Bradshaw, Goldweber, Garbarino and James (2013) revealed a significant relation between relatively mild levels of social - environmental risk and aggression. This association was partially mediated by negatively biased social - cognitive factors (i.e., general knowledge structures and social information processing). Findings suggest that even relatively low levels of

social rejection and community violence exposure characterizing suburban youth put them at an increased risk of problems with aggression. 


\section{Risk Factors of Adolescent Aggression}

Several longitudinal studies and meta-analytic reviews have demonstrated that exposure to violent media is linked to aggression over time. Coyne and Archer (2004) studied 347 British adolescents and revealed that indirectly aggressive girls viewed more indirect aggression on television than non-aggressive girls did. It could be that after viewing rewarded gossiping, backbiting and rumour spreading, these girls are particularly likely to use this form of aggression in their own lives.

Thus, the genetic disposition of the individual, the disciplinary styles adopted by the parents, the school set-up and the environment in which the learners are situated could enhance their aggression. Through observational experiences an adolescent can develop into an aggressor via media influences.

\section{Objectives}

1. Prevalence of aggression among the respondents.

2. Risk factors of aggression.

\section{Hypothesis}

o Males are more aggressive than females.

\section{METHODS AND MATERIALS}

The purpose of this study is to determine the risk factors related to aggressive behaviour among late adolescents. To this end, a quantitative approach has been used. The selected design is a survey design. The Universe of the study comprises the Autonomous colleges offering undergraduate degree course in Mangaluru city. Purposive sampling technique is used to select the respondents possessing high aggression. All the first year degree students, both male and female adolescents aged between 17 and 19 years who volunteered for the study from the three Colleges, scoring high on the Aggression Scale (score 205 and above) have been included in the study. The required data has been elicited by administering the Aggression Scale developed by Mathur and Bhatnagar (2004).

\section{RESULTS AND DISCUSSION}

\section{Table 1 Prevalence of aggression among the respondents}

\begin{tabular}{|l|c|c|l|l|}
\hline & $\begin{array}{c}\text { High } \\
\text { Aggression }\end{array}$ & $\begin{array}{c}\text { Low to Average } \\
\text { Aggression }\end{array}$ & \multicolumn{1}{|c|}{ Total } & Chi square Test \\
\hline Males & $41(65.1 \%)$ & $22(34.9 \%)$ & 63 & $\mathrm{X} 2=24.094$ \\
\hline Females & $73(31.19 \%)$ & $161(68.8 \%)$ & 234 & $\begin{array}{l}p \text { value } \\
0.000\end{array}$ \\
\hline & $114(38.38 \%)$ & $183(61.61 \%)$ & 297 & $<0.00$ HS \\
\hline
\end{tabular}

High aggression is seen among $65.1 \%$ of males and $31.3 \%$ of females. The results show a statistical significant association between gender and aggression with $\mathrm{X} 2=24.094$. Thus, there is 


\section{Risk Factors of Adolescent Aggression}

a highly significant relation between the two groups. The hypothesis is proved. Males are found to be more aggressive than females as per the findings of Ghosh (2013) and Biswas (1989).

\section{Table 2 Comparison between aggression and other variables}

\begin{tabular}{|c|c|c|c|c|c|c|}
\hline & \multicolumn{2}{|c|}{ Chi square Test } & \multirow[b]{2}{*}{$\begin{array}{l}p \\
\text { value }\end{array}$} & & \multicolumn{2}{|c|}{$\begin{array}{l}\text { Fishers } \\
\text { Exact Test }\end{array}$} \\
\hline & $\mathbf{X} 2$ & df & & & $\begin{array}{l}p \\
\text { value }\end{array}$ & \\
\hline Sex and Aggression & 24.094 & 1 & .000 & HS & . & . \\
\hline Religion and Aggression & 2.068 & 2 & .356 & NS & & \\
\hline Living Condition and Aggression & 0.436 & 1 & .509 & NS & & \\
\hline Socio-Economic Status and Aggression & . & & & & .004 & HS \\
\hline Presence of Parental Figures and Aggression & 0.195 & 2 & .907 & NS & & \\
\hline Discipline and Aggression & . & & & & .659 & NS \\
\hline Family Environment and Aggression & 2.048 & 2 & .359 & NS & & \\
\hline Peers and Aggression & . & & & & .718 & NS \\
\hline Peers Fights and Aggression & . & & & & .595 & NS \\
\hline Teachers and Aggression & . & & & & .892 & NS \\
\hline Community and Aggression & . & & & & .238 & NS \\
\hline $\begin{array}{l}\text { Engage in aggressive TV programmes and } \\
\text { Aggression }\end{array}$ & 0.721 & 2 & .697 & NS & & \\
\hline $\begin{array}{l}\text { Engage in bullying classmates and } \\
\text { neighbours and Aggression }\end{array}$ & 2.291 & 2 & .318 & NS & & \\
\hline
\end{tabular}

The results in Table 2 clearly show that there is a statistical significant association between sex and aggression (X2=24.094). According to the theories of aggression by Parke and Slaby (1983), gender role and learning play a key role for anger and aggressive behaviour among males. Males are exposed to parenting practices that promote rough-and-tumble, anger and aggressive behaviours whereas females are exposed to parenting practices that promote caring and close interpersonal relationships. These differential socialization practices appear to foster adolescents' anger to a greater extent in males than in females. Also, there is a high significance between the socio - economic status of the respondents and aggression. One probable explanation of this finding might be related to the domain-specific theory of self-esteem (Baumeister, 1998; Kirkpatrick, Waugh, Valencia \& Webster, 2002) which states that functionally distinct domains of self-esteem would predict aggression differentially.

Adolescents with high socio - economic status perceive superiority. Individuals with low socio economic status, however, perceive social exclusion. Thus, social superiority and social exclusion emerge as reliable and positive predictors of aggression (Bushman \& Baumeister, 1998). The findings of the present study may be approached from the view-point of these

(c) The International Journal of Indian Psychology, ISSN 2348-5396 (e)| ISSN: 2349-3429 (p) | 153 


\section{Risk Factors of Adolescent Aggression}

theoretical perspectives. However, there is no significance between aggression and the other demographic variables.

Table 3 Demographic details of the respondents

\begin{tabular}{|c|c|c|c|c|c|c|c|}
\hline & \multicolumn{6}{|c|}{ Aggression } \\
\hline & & \multicolumn{2}{|c|}{$\begin{array}{c}\text { High } \\
\text { Aggression } \\
\end{array}$} & \multicolumn{2}{|c|}{ Average/Low } & \multicolumn{2}{|c|}{ Total } \\
\hline & & Freq & $\%$ & Freq & $\%$ & Freq & $\%$ \\
\hline \multirow[t]{2}{*}{ Sex } & Male & 41 & 65 & 22 & 34 & 63 & 100 \\
\hline & Female & 73 & 31 & 161 & 68 & 234 & 100 \\
\hline \multicolumn{2}{|l|}{ Total } & 114 & & 183 & & 297 & \\
\hline \multirow[t]{3}{*}{ Religion } & Hindus & 36 & 35.0 & 67 & 65.0 & 103 & 100 \\
\hline & Muslims & 31 & 45.6 & 37 & 54.4 & 68 & 100 \\
\hline & Christians & 47 & 37.3 & 79 & 62.7 & 126 & 100 \\
\hline \multicolumn{2}{|l|}{ Total } & 114 & & 183 & & 297 & \\
\hline \multirow[t]{2}{*}{ Living Conditions } & At Home & 66 & 36.9 & 113 & 63.1 & 179 & 100 \\
\hline & In The Hostel/PG & 48 & 40.7 & 70 & 59.3 & 118 & 100 \\
\hline \multicolumn{2}{|l|}{ Total } & 114 & & 183 & & 297 & \\
\hline \multirow[t]{3}{*}{$\begin{array}{l}\text { Socio - Economic } \\
\text { Conditions }\end{array}$} & \begin{tabular}{|ll} 
Upper $\quad$ Middle \\
Class
\end{tabular} & 36 & 54.5 & 30 & 45.5 & 66 & 100 \\
\hline & Middle Class & 77 & 34.4 & 147 & 65.6 & 224 & 100 \\
\hline & $\begin{array}{ll}\text { Lower } \quad \text { Middle } \\
\text { Class }\end{array}$ & 1 & 14.3 & 6 & 85.7 & 7 & 100 \\
\hline \multicolumn{2}{|l|}{ Total } & 114 & & 183 & & 297 & \\
\hline \multirow[t]{4}{*}{ At Home } & $\begin{array}{l}\text { Both Parents } \\
\text { Living Together }\end{array}$ & 81 & 37.7 & 134 & 62.3 & 215 & 100 \\
\hline & Single Parent & 23 & 39.7 & 35 & 60.3 & 58 & 100 \\
\hline & $\begin{array}{l}\text { With Relatives and } \\
\text { Grandparents }\end{array}$ & 10 & 41.7 & 14 & 58.3 & 24 & 100 \\
\hline & TOTAL & 114 & & 183 & & 297 & \\
\hline
\end{tabular}

Majority of the adolescents (179) are day scholars pursuing their collegiate education. As reported by them, 224 adolescents report belonging to the middle socio - economic strata of society. A majority of 215 adolescents hail from families where both the parents live together.

(c) The International Journal of Indian Psychology, ISSN 2348-5396 (e)| ISSN: 2349-3429 (p) | 154 
Risk Factors of Adolescent Aggression

Table 4 Risk factors of aggression

\begin{tabular}{|c|c|c|c|c|c|c|c|}
\hline & & \multicolumn{6}{|c|}{ Aggression } \\
\hline & & \multicolumn{2}{|c|}{$\begin{array}{c}\text { High } \\
\text { Aggression }\end{array}$} & \multicolumn{2}{|c|}{ Average/Low } & \multicolumn{2}{|c|}{ TOTAL } \\
\hline & & Freq & $\%$ & Freq & $\%$ & Freq & $\%$ \\
\hline \multirow{3}{*}{ Discipline } & Unreasonably strict & 7 & 43.8 & 9 & 56.3 & 16 & 100 \\
\hline & $\begin{array}{ll}\begin{array}{l}\text { Strict } \\
\text { reasonable }\end{array} & \text { but }\end{array}$ & 103 & 37.7 & 170 & 62.3 & 273 & 100 \\
\hline & Uninvolved & 4 & 50.0 & 4 & 50.0 & 8 & 100 \\
\hline \multicolumn{2}{|l|}{ TOTAL } & 114 & & 183 & & 297 & \\
\hline \multirow[t]{3}{*}{ Family Environment } & Excellent & 32 & 35.6 & 58 & 64.4 & 90 & 100 \\
\hline & Good & 71 & 38.2 & 115 & 61.8 & 186 & 100 \\
\hline & Average & 11 & 52.4 & 10 & 47.6 & 21 & 100 \\
\hline \multicolumn{2}{|l|}{ TOTAL } & 114 & & 183 & & 297 & \\
\hline \multirow[t]{3}{*}{ Peers } & \begin{tabular}{|l} 
Loving/Caring \\
\end{tabular} & 77 & 37.4 & 129 & 62.6 & 206 & 100 \\
\hline & Aggressive/Violent & 4 & 50.0 & 4 & 50.0 & 8 & 100 \\
\hline & Ordinary/Neutral & 33 & 39.8 & 50 & 60.2 & 83 & 100 \\
\hline \multicolumn{2}{|l|}{ TOTAL } & 114 & & 183 & & 297 & \\
\hline \multirow{3}{*}{ Peers Fights } & Always & 2 & 66.7 & 1 & 33.3 & 3 & 100 \\
\hline & Sometimes & 39 & 36.1 & 69 & 63.9 & 108 & 100 \\
\hline & Never & 73 & 39.2 & 113 & 60.8 & 186 & 100 \\
\hline \multicolumn{2}{|l|}{ TOTAL } & 114 & & 183 & & 297 & \\
\hline \multirow[t]{4}{*}{ Teachers } & Loving & 79 & 40.1 & 118 & 59.9 & 197 & 100 \\
\hline & Unreasonably Strict & 3 & 33.3 & 6 & 66.7 & 9 & 100 \\
\hline & Reasonable Strict & 31 & 35.2 & 57 & 64.8 & 88 & 100 \\
\hline & \begin{tabular}{|l} 
Aggressive/Violent \\
\end{tabular} & 1 & 33.3 & 2 & 66.7 & 3 & 100 \\
\hline \multicolumn{2}{|l|}{ TOTAL } & 114 & & 183 & & 297 & \\
\hline \multirow[t]{3}{*}{ Community } & \begin{tabular}{|l} 
Loving/Caring \\
\end{tabular} & 62 & 34.6 & 117 & 65.4 & 179 & 100 \\
\hline & Aggressive/Violent & 3 & 42.9 & 4 & 57.1 & 7 & 100 \\
\hline & Ordinary/Neutral & 49 & 44.1 & 62 & 55.9 & 111 & 100 \\
\hline \multicolumn{2}{|l|}{ TOTAL } & 114 & & 183 & & 297 & \\
\hline \multirow{4}{*}{$\begin{array}{lr}\text { Engage } & \text { In } \\
\text { Aggressive } & \text { T.V } \\
\text { Programmes } & \\
\end{array}$} & Always & & & & & & \\
\hline & & 11 & 45.8 & 13 & 54.2 & 24 & 100 \\
\hline & Sometimes & 77 & 38.3 & 124 & 61.7 & 201 & 100 \\
\hline & Never & 26 & 36.1 & 46 & 63.9 & 72 & 100 \\
\hline \multicolumn{2}{|l|}{ TOTAL } & 114 & & 183 & & 297 & \\
\hline \multirow[t]{3}{*}{$\begin{array}{lr}\text { Engage in } & \text { Bullying } \\
\text { Classmates } & \text { and } \\
\text { Neighbours } & \\
\end{array}$} & Always & 2 & 22.2 & 7 & 77.8 & 9 & 100 \\
\hline & Sometimes & 54 & 42.5 & 73 & 57.5 & 127 & 100 \\
\hline & Never & 58 & 36.0 & 103 & 64.0 & 161 & 100 \\
\hline \multicolumn{2}{|l|}{ TOTAL } & 114 & & 183 & & 297 & \\
\hline
\end{tabular}

(C) The International Journal of Indian Psychology, ISSN 2348-5396 (e)| ISSN: 2349-3429 (p) | 155 


\section{Risk Factors of Adolescent Aggression}

Table 4 shows $43.8 \%$ of highly aggressive adolescents and $56.3 \%$ of average/low aggressive adolescents report unreasonably strict parental discipline. $64.4 \%$ of average/low aggressive adolescents consider their family environment to be excellent whereas only $35.6 \%$ of highly aggressive adolescents feel the same about their families. A large majority of the (52.4\%) highly aggressive adolescents consider their family environment to be average compared to the average/low aggressive adolescents (47.6\%). 62.6\% of the average/low aggressive adolescents consider their peers to be loving and caring whereas only $37.4 \%$ of the highly aggressive adolescents feel the same about their peers. $66.7 \%$ of the highly aggressive adolescents expressed that their peers always fought with them and only $33.3 \%$ of the average/low aggressive adolescents expressed so. A larger majority of the average/low aggressive adolescents (59.9\% ) considered their teachers to be loving compared to the highly aggressive adolescents (40.1\%). Compared to their counterparts, 66.7\%, $64.8 \%$ and $66.7 \%$ of the average/low aggressive adolescents considered their teachers to be more unreasonably strict, more reasonably strict and more aggressive, respectively. 57.1\% of the average/low aggressive adolescents considered their community to be more aggressive and violent compared to the highly aggressive adolescents (42.9\%). A higher majority of the average/low aggressive adolescents (54.2\%) always engaged in aggressive TV programmes than the highly aggressive adolescents (45.8\%). Surprisingly, the average/low aggressive adolescents always engaged in bullying behaviour more (77.8\%) than the highly aggressive adolescents (22.2\%).

\section{IMPLICATIONS OF THE STUDY}

This study on the risk factors of adolescent aggression revealed the presence of differences in gender and socio - economic status among aggressive late adolescents. As reported by them, many adolescents belong to the middle socio-economic strata of the society. During the period of adolescence, there are experiences of peer rejection, academic failure and lowered self-esteem. One continues to be persistently aggressive in interactions with both peers and adults and is at risk of social rejection. Arguments with parents and siblings may increase and the adolescent may develop other significant behaviour problems. To be healthy and safe, adolescents need to be equipped with skills that allow them to cope with anger in a productive manner. The nature of changes and challenges that occur simultaneously during adolescence require the development of effective coping strategies for adaptive functioning.

\section{CONCLUSIONS}

In today's society, adolescents face daily situations that contribute to their anger. A major contribution of the current study is the exploration of the association of adolescent's anger with sex and SES of a few adolescents of Mangaluru city. But the sample size was relatively small and the study was administered in Autonomous colleges only. Future research can be carried out on a large-scale sample covering different other colleges like government, private aided and private colleges. Further studies are needed to measure and investigate the components (instrumental anger, reactive anger and anger control) of anger. However, identifying and 


\section{Risk Factors of Adolescent Aggression}

understanding protective factors are equally important as researching risk factors. Future studies may also wish to explore aspects of anger coping and its relationship with SES, gender and other demographic factors. It would be imperative to study and analyse the hidden causal factors of aggression, impulsivity, problems faced personally, at home or in academics as these problems would precipitate and prevent the experience of psychological well- being. Thus identification of causal factors would facilitate developing early preventive/curative interventions by mental health professionals which would ensure better mental health among the adolescent population.

\section{Acknowledgments}

The author appreciates all those who participated in the study and helped to facilitate the research process.

\section{Conflict of Interests}

The author declared no conflict of interests.

\section{REFERENCES}

Adams, D. W. (1966). The family: A sociological interpretation. Child Development, 6(2), 56-63.

Baumeister, R. F. (1998). The self. In D. T. Gilbert, S. T. Fiske, \& G. Lindzey (Eds.), The handbook of social psychology ( $4^{\text {th }}$ ed., Vol.1, pp. 680-740). Boston: McGraw-Hill.

Biswas, P. C. (1989). Directions of aggression of school going adolescents as related to family tension, area of residence and sex: A comparative study. Manas, 6(36), 1-9.

Bradshaw, C. P., Goldweber, A., \& Garbarino, J. (2013). .Linking social-environmental risk factors with aggression in suburban adolescents: The role of social-cognitive mediators. Psychology in the Schools, 50(5), 433-450.

Bronfenbrenner, U. (2001). The theory of human development. In N. J. Smelser, \& P. B. Baltes (Eds.), International encyclopedia of the social and behavioural sciences (Vol. 10, pp.6963-6970). New York: Elsevier.

Bushman, B. J., \& Baumeister, R. F. (1998). Threatened egotism, narcissism, self-esteem, and direct and displaced aggression: Does self-love or self-hate lead to violence? Journal of Personality and Social Psychology, 75, 219-229.

Coie, J. D., \& Dodge, K. A. (1997). Aggression and antisocial behavior. In W. Damon, \& N. Eisenberg (Eds.), Handbook of child psychology, Vol. 3: Social, emotional and personality development (5th ed.), in press.

Coyne, S. M., \& Archer, J. (2004). Indirect aggression in the media: A content analysis of British television programs. Aggressive Behaviour, 30(3), 254-271.

Ghosh, S. M. (2013). A comparative study on aggression between boys and girls adolescent. International Journal of Behavioural Social and Movement Sciences 02(03), 76-82.

Jayanagaraja, R. (1985). The enigma of life - The adolescence. Child Psychiatry Quarterly, 18(4), 110-112. 


\section{Risk Factors of Adolescent Aggression}

Kirkpatrick, L. A., Waugh, C. E., Valencia, A., \& Webster, G. D. (2002). The functional domain specificity of self-esteem and the differential prediction of aggression. Journal of Personality and Social Psychology, 82 (5), 756-767.

Maccoby, E. E., \& Jacklin, C. N. (1974). The psychology of sex differences. Stanford, CA: Stanford University Press.

Mathur, G. P., \& Bhatnagar, R. (2004). Aggression scale. Agra, India: Rakhi Prakashan.

Parke, R. D., \& Slaby, R. G.(1983). The development of aggression. In P. H. Mussen (Series Ed.), \& E. M. Hetherington (Vol. Ed.), Handbook of child psychology, Vol.4, Socialization, personality, and social development (4th ed.). New York: Wiley.

Patterson, G. R., Chamberlain, P., \& Reid, J. B. (1982). A comparative evaluation of parent training procedures. Behaviour Therapy, 13, 638-650.

Rahman, A. K. M. R., \& Huq, M. M. (2005). Aggression in adolescent boys and girls as related to socio-economic status and residential background. Journal of life Earth Science, 1(1), 5-9.

Sharma, R., Grover, V. L., \& Chaturvedi, S. (2008). Risk behaviours related to inter-personal violence among school and college-going adolescents in south Delhi. Indian Journal of Community Medicine, 33(2): 85-8.

Van Londen, S. S., Deković, M., Prinzie, M., de Castro, P., Lochman, B. O., \& John, E. (2013). Simultaneously testing parenting and social cognitions in children at-risk for aggressive behaviour problems: Sex differences and ethnic similarities. Journal of Child and Family Studies, 22(7), 922-931.

How to cite this article: S Lobo, S Rekha (2016), Risk Factors of Adolescent Aggression, International Journal of Indian Psychology, Volume 3, Issue 4, No. 57, ISSN 2348-5396 (e), ISSN: 2349-3429 (p), DIP: 18.01.036/20160304, ISBN: 978-1-365-23993-9 